\title{
Nauka prawa w sztuce filmów animowanych ${ }^{1}$
}

Sztuka i nauka są koegzystującymi dziedzinami działalności ludzkiej, których relacja często jest uwarunkowana kontekstem kulturowym. Mogą one być tożsame - jak na przykład teksty filozoficzne, czerpać z siebie, chociażby poprzez prowadzenie rozważań akademickich nad sztuką lub wplatanie naukowych treści do dzieł artystycznych, czy też stać w opozycji, negując wzajemnie swoje racje. Niniejsze opracowanie ma na celu zbadanie tych zależności w ściśle ujętym kontekście, a mianowicie na podstawie analizy związków treści prawnonaukowych z filmami animowanymi. Termin „nauka prawa” dla potrzeb niniejszej pracy należy rozumieć dwojako - jako szeroko pojmowane treści należące do poszczególnych dyscyplin nauk prawnych, które zostały umieszczone w badanych utworach, ale także jako proces nauczania o prawie lub poprzez prawo, który zachodzi, nawet nieświadomie, jako rezultat kontaktu widza, zwłaszcza najmłodszego, z filmami animowanymi. Oba ujęcia są ze sobą ściśle związane, ponieważ wspomniany wymiar edukacyjny oraz wychowawczy tych utworów jest w badanym ujęciu zdeterminowany przez treści prawnonaukowe. Zasygnalizowany problem nabiera doniosłości w zestawieniu z faktem, że przemyst filmowy stanowi jedną z najbardziej dochodowych gatęzi sektora rozrywkowego². Szczególnie osobliwą pozycję na rynku zajmują właśnie filmy animowane, które - choć pierwotnie przeznaczone były dla dzieci - swoim sukcesem kulturowym i komercyjnym znacznie wykroczyły poza docelową grupę odbiorców. Fenomen ten był już wielokrotnie poddawany licznym badaniom z różnych dziedzin (Wang, 2012: 7-17), jednakże jego skala uzasadnia potrzebę dokonywania ciągłej aktualizacji i poszerzania stanu wiedzy. Podstawę analizy stanowi dziesięć najbardziej dochodowych tytułów³:

1 Praca powstała w 2018 roku w toku realizacji projektu badawczego w ramach konkursu BestStudentGrant UAM, skierowanego do studentów I i ll roku studiów I stopnia i jednolitych studiów magisterskich.

2 Według danych stowarzyszenia Motion Picture Association tylko w 2016 roku światowych dochód rynku filmowego wyniósł 38,6 miliardów dolarów (Making Sense..., 2017), a zgodnie z prognozami wartość ta będzie rosnąć.

3 Podane kryterium oznacza międzynarodową wartość box office wyrażoną w dolarach. Pozwala ono maksymalnie zobiektywizować dobór utworów oraz wskazuje na najbardziej reprezentatywne filmy swojego gatunku. 
1. Frozen/Kraina lodu (reż. Chris Buck, Jennifer Lee, 2013 r.)

- 1274234980 dolarów;

2. Minions/Minionki (reż. Pierre Coffin, Kyle Balda, 2015 r.)

- 1167245366 dolarów;

3. Toy Story 3 (reż. Lee Unkrich, 2010 r.) - 1069818229 dolarów;

4. Despicable Me 3/Gru, Dru i Minionki (reż. Pierre Coffin, Kyle Balda, 2017 r.)

- 1031562398 dolarów;

5. Finding Dory/Gdzie jest Dory? (reż. Andrew Stanton, 2016 r.)

- 1022617376 dolarów;

6. Zootopia/Zwierzogród (reż. Byron Howard, Rich Moore, Jared Bush, 2016 r.) - 1019920974 dolarów;

7. The Lion King/Król Lew (reż. Roger Allers, Rob Minkoff, 1994 r.)

- 987480140 dolarów;

8. Despicable Me 2/Minionki rozrabiajq (reż. Pierre Coffin, Chris Renaud, 2013 r.) - 975216835 dolarów;

9. Shrek 2 (reż. Andrew Adamson, Conrad Vernon, Kelly Asbury, 2004 r.) - 937008132 dolarów;

10. Finding Nemo/Gdzie jest Nemo? (reż. Andrew Stanton, Lee Unkrich, 2003 r.) - 936429370 dolarów4.

Krótkiego wyjaśnienia wymaga kwestia, dlaczego moim zdaniem prawo w filmach animowanych może zostać uznane za element dostatecznie istotny, by poddać go analizie. Wpływ kultury na społeczeństwo jest bezsporny. Szczególnie narażoną i podatną na wszelkie oddziaływania grupą społeczną są dzieci. Podobne obserwacje poczynił między innymi Lew Wygotski, rosyjski badacz, który w swojej społeczno-kulturowej teorii rozwoju jako jedno z założeń przyjął to, że „rozwój intelektualny dziecka jest blisko powiązany z jego kulturą” (Schaffer, Kipp, 2015: 266). Fakt ten w zestawieniu z popularnością filmów animowanych przemawia za podjęciem się analizy tego gatunku w kontekście potencjalnego wpływu na najmłodszych. Dodatkowym argumentem może być również niezwykła popularność produktów z wizerunkami bohaterów w nich występujących, które są sprzedawane w ramach merchandisingu. Oznacza to w istocie, że dzieci mogą utrzymywać z tymi postaciami stały kontakt. Według różnych teorii, chociażby percepcji podprogowej, może to prowadzić do skutecznej manipulacji. Nie wdając się jednak w spór o to, czy taki przekaz jest efektywny, należy wskazać, że ów wpływ poprzez filmy animowane może zachodzić także jako rezultat bezpośredniej propagandy lub realizacji scenariusza bez zamiaru przekazania określonych treści. W kontekście niniejszej analizy metoda oddziaływania na widzów ma znaczenie

4 Dane pochodzą od przedsiębiorstwa Nash Information Services, LLC, stan na 14 listopada 2017 roku (The Numbers, b.r.). 
drugorzędne, a istotne są wyłącznie: sam fakt zachodzenia takiego zjawiska oraz techniki konstrukcyjne wykorzystywane do wpływania na odbiorców. Uważam, że istotnym elementem tego mechanizmu jest motyw prawa prezentowany w tekstach kultury. Aby umożliwić przekazywanie widzom sprecyzowanych treści, świat fikcyjny musi być odpowiednio zbudowany. Z moich obserwacji wynika, że bardzo często akcja filmu animowanego jest wyznaczana właśnie ramami prawnymi i należy to rozumieć zarówno jako umieszczanie bohaterów w określonych sytuacjach prawnych, uwikłanie ich w różnorodne stosunki, jak i powiązanie głównego wątku ze zdarzeniami prawnymi. Wobec tego elementy normatywne jawią się nie tylko jako czynniki konstruujące ukazaną rzeczywistość, ale także pozwalające na transfer określonych idei. Wobec powyższego uznałem, że motyw prawa wyróżnia się na tle innych czynników konstytuujących świat fikcyjny. Prawo przejawia się w filmach animowanych na wiele sposobów. Przybiera ono formę czynności o charakterze publicznoprawnym lub prywatnoprawnym ${ }^{5}$. Może być oczywiste do wychwycenia albo też radykalnie nieintuicyjne. Gdyby zadać pytanie, czym jest prawo w filmach animowanych, byłoby nim zapewne to, co jest nim w rzeczywistym świecie ${ }^{6}$. W ten sposób możliwe będzie ustalenie, jak funkcjonuje na przykład świat morski w Gdzie jest Nemo? i Gdzie jest Dory? Za przyjęciem takiego założenia przemawia także to, że każda historia przedstawiona w filmach animowanych, bez względu na to, jaka ona jest lub kim są jej bohaterowie, korzysta ze struktur rzeczywistych. Normy prawne, nawet jeśli niewidoczne, pełniłyby w tym kontekście funkcję czynnika, który porządkuje świat, ułatwia odbiór historii i ustanawia ład sprzyjający przejrzystości utworu. Uważam, że w przypadku filmów animowanych ta porządkująca rola prawa jest szczególnie istotna, ponieważ z jednej strony stoi na straży czytelności dzieła, co należy uznać za ważną funkcję ze względu na tzw. target, czyli grupę docelową filmu, którą stanowią głównie najmłodsi, a z drugiej jest cennym i elastycznym budulcem historii. Występujące w nich intrygi nierozerwalnie łączą się z tym, że bohaterowie dla osiągnięcia swoich celów wykorzystują lub łamią prawo, a nierzadko to właśnie zmiana sytuacji

5 Prawo publiczne obejmuje regulacje, które dotyczą organu lub podmiotu występującego w sytuacji nadrzędnej w stosunku do innego uczestnika stosunków społecznych (na przykład organ państwa w stosunku do obywateli). Prawo prywatne porządkuje natomiast relacje między podmiotami formalnie równymi (Wronkowska, 2005: 111-113).

6 Mowa tu jednak nie o treści tego prawa, a o sposobie jego definiowania. Profesor Sławomira Wronkowska-Jaśkiewicz twierdzi, że prawo to „zbiór norm postępowania ustanowionych albo uznanych przez kompetentne (upoważnione) organy państwa” (Wronkowska, 2005: 11). Idąc dalej, należałoby również przyjąć, że normy postępowania wyrażają pewne nakazy i zakazy (Wronkowska, 2005: 13). W tym świetle przedmiotem zainteresowania niniejszego opracowania są pewne prawnie regulowane zachowania o określonym skutku, będące przedmiotem jakiegoś obowiązku albo w związku z którymi może powstać taki obowiązek. 
prawnej jest motorem pobudzającym do działania ${ }^{7}$. Tabela 1 zawiera wybrane przykłady konstruktów normatywnych (o różnym stopniu szczegółowości) zamieszczonych w badanych filmach animowanych.

Tabela 1. Przykładowe konstrukcje prawne

\begin{tabular}{|l|l|}
\hline Przestępstwo & $\begin{array}{l}\text { Kraina Lodu, Minionki, Gru, Dru i Minionki, Zwierzogród, Gdzie jest Dory?, Król Lew, Minionki rozrabiajq, } \\
\text { Toy Story 3, Shrek2 }\end{array}$ \\
\hline Władza & Kraina Lodu, Minionki, Zwierzogród, Król Lew, Shrek 2, Toy Story 3 \\
\hline Umowa & Minionki, Shrek 2, Król Lew \\
\hline Małżeństwo & $\begin{array}{l}\text { Kraina Lodu, Minionki, Gru, Dru i Minionki, Gdzie jest Nemo?, Gdzie jest Dory?, Zwierzogród, Król Lew, } \\
\text { Minionki rozrabiaja, Shrek2 }\end{array}$ \\
\hline
\end{tabular}

Źródło: opracowanie własne.

Powyższe zespoły norm i ich realizacje są dobrane całkowicie subiektywnie, a celem takiego zestawienia jest wyłącznie zasygnalizowanie, czym może być prawo w filmach animowanych. Bez wątpienia można wskazać więcej konstruktów występujących w tego typu utworach i dodać do określonych w tabeli 1 kategorii inne tytuły z podanej we wstępie listy, w zależności od dociekliwości oraz spojrzenia na historię. Jednakże moim celem było uwzględnienie tych konstrukcji, które odgrywają istotną rolę na tle przedstawionej historii. Stworzenie wyczerpującego ich katalogu byłoby nie tylko czasochłonne czy wręcz trudno osiągalne, ale także zbędne.

W kontekście niniejszej analizy istotna jest percepcja prawa fikcyjnego przez widza. Jest ona rezultatem przedstawienia określonych zachowań bohaterów w utworze. Na podstawie uwag zamieszczonych w poprzednich akapitach można stwierdzić, że konstrukcja porządku prawnego pełni doniosłą funkcję w procesie interpretacji utworu - determinuje wszakże wiele kluczowych z punktu widzenia historii stanów rzeczy. Zagadnienie to można przybliżyć, odpowiadając na poniższe pytania:

1. Jak jest skonstruowane prawo fikcyjne?

2. Gdzie sięgają granice przedstawionych regulacji, a gdzie granice ich poznania?

3. Czy tłumacz ma wpływ na przedstawiony w utworze system prawny?

7 Intryga Zwierzogrodu koncentruje się na dążeniu do przejęcia fotela burmistrza; główny antagonista z Krainy Lodu robi wszystko, by zostać królem; protagoniści Gru, Dru i Minionków zmierzają do odzyskania skradzionego diamentu, a więc zniweczenia skutków przestępstwa. 
Ad 1. Postawione pytanie dotyczy w rzeczywistości wątpliwości, jakiego typu normy fikcyjne występują w utworach i jakie jest ich źródło. W przypadku utworów, których akcja toczy się w możliwych do zidentyfikowania państwach (takimi dziełami są Minionki czy Gdzie jest Nemo?), łatwo przyporządkować porządek prawny do świata fikcyjnego, ale i tutaj występują znaczne rozbieżności. W Minionkach bohaterowie, będący monarchami angielskimi, dokonują czynności, które znacznie wykraczają poza kompetencje królewskie z ukazanego okresu historycznego (chociażby stosują karę śmierci). Z drugiej strony w filmach osadzonych w wykreowanej rzeczywistości (na przykład Zwierzogrodzie czy Shreku 2) takie proste przyporządkowanie systemu prawnego do filmu wydaje się nieuzasadnione. Jakie więc normy obowiązują i w jakiej formie? Pewne jest, że bohaterowie mają przypisane wartości, którym hołdują, oraz prawa, których przestrzegają (lub które łamią). Królowa Elsa jako władczyni kieruje się normami krajowymi, a jako osoba mająca magiczne zdolności podąża za własnym sumieniem. Z kolei małżeństwa zawierane w świątyniach bez wątpienia wiążą się z występowaniem norm religijnych (powiązanych w tym zakresie z normami o charakterze prawnym), a gdy któryś z bohaterów buntuje się przeciwko okrucieństwu prawa pozytywnego, powołuje się w istocie na prawo naturalne (zob. Radbruch, 2008). Normy te można więc dostrzec poprzez analizę postaci - uzewnętrzniają się one w dialogach oraz w podejmowanych działaniach. Pozostałe elementy utworu sygnalizują natomiast istnienie pewnych regut, które utrzymują ład w ukazanym świecie. Należą one głównie do domeny prawa publicznego, regulując w szczególności takie kwestie jak ustrój państwa oraz relacje między władzą a jednostką, ale także do prawa prywatnego na podstawowym poziomie stosunków społecznych. Chodzi zatem o wszelkie zachowania, które dla efektywnego działania wymagają odpowiednich regulacji prawnych. Filmy animowane co do zasady nie zdradzają bezpośrednio, jakie jest źródło praw, na których opiera się świat fikcyjny. Kwestia ta pozostaje bez znaczenia dla prezentowanej historii oraz obowiązywania norm. Istotne jest więc to, że istnieją stosowne regulacje, a nie jakie jest ich źródło. Warto także zauważyć, że jako widzowie mamy bardzo swobodne podejście do odbierania norm fikcyjnym. Nie dziwi przecież nikogo to, że dany bohater dysponuje kompetencją umożliwiającą mu dokonanie absurdalnej lub szokującej czynności, tylko fakt jej dokonania. Zjawisko to udowadnia, jak atrakcyjne mogą być dla scenarzystów wątki prawne ze względu na ogromną tolerancję odbiorców. W tym kontekście pierwiastek naukowy występuje jako czynnik pozwalający na naturalne i zgrabne udoskonalanie czy też uwypuklanie określonych elementów danego dzieła, bez konieczności wyjaśniania, dlaczego bohater mógł dokonać danej czynności. 
Ad 2. Już na samym początku należy zasygnalizować podstawową przeszkodę w ukazywaniu fikcyjnego systemu. Niemożliwe jest z jednej strony przedstawienie wszystkich obowiązujących norm, a z drugiej dokładne ukazanie występujących regulacji, nie rozwijając problemu ich przystępności. Trudność ta wynika stąd, że rzeczywistość jest zbyt skomplikowana, by zidentyfikować wszystkie obowiązujące normy bez względu na ich rodzaj. Oznacza to, że twórcy tekstów kultury nie mogą uniknąć pewnych niedociągnięć, sprzeczności i pominięć. Z całą pewnością zakres ukazanych regulacji jest większy od tego, jaka była intencja autora, a to dlatego, że nikt nie jest w stanie przewidzieć wszystkich możliwych wariantów interpretacji tekstu. Chodzi tu o sytuację, w której twórca w ogóle nie miał zamiaru wprowadzać treści prawnych (na przykład poprzez ukazanie specyficznego zwyczaju) albo gdy widz odczytuje przedstawione elementy niezgodnie z intencją scenarzystów. Wobec powyższego należy stwierdzić, że granice systemu fikcyjnego są elastyczne i spersonalizowane, a nie sztywno ustalone. Pytanie o możliwość poznania przedstawionych regulacji jest problematyczne przede wszystkim dlatego, że widz w trakcie odbierania jakiegokolwiek tekstu kultury nie jest w stanie poznać całego fikcyjnego systemu prawa. Dzieje się tak z kilku powodów. Po pierwsze, treści prawne nie przyciągają same w sobie uwagi. To wydarzenia wynikające z norm prawnych pozostają na pierwszym planie, a nie samoistne normy czy fakt ich obowiązywania. Po drugie, problematyka bytu regulacji prawnych jest nieatrakcyjna dla odbiorców filmów animowanych. Jest to tematyka trudna i z całą pewnością kłócąca się z rozrywkowym charakterem tego gatunku filmowego. Powyższe założenia prowadzą do wniosków, że granice poznania tych regulacji są wyznaczone przez rozwój historii i wydarzenia, które odbiorca śledzi, oraz że widz może nie zdawać sobie sprawy, że w rzeczywistości na ekranie ukazane zostało funkcjonowanie norm fikcyjnego systemu prawnego. Taki stan rzeczy silnie obrazuje podporządkowanie treści naukowych potrzebom tekstu kultury.

Ad 3. Zasygnalizowany problem wiąże się z wątpliwością co do potencjalnego wpływu tłumacza na fikcyjne regulacje. Dokładne, wierne tłumaczenie wypowiedzi niosących treści prawne jest niemożliwe ze względu na złożoność samego procesu przekładu (Clouet, Sánchez Hernández, 2004: 70) oraz specyfikę tłumaczenia prawnego i prawniczego (Monjean-Decaudin, 2012: 129-130). Tłumacz musi brać pod uwagę wiele czynników, wśród których odwzorowanie treści prawnych z całą pewnością nie należy do najważniejszych, jeśli w ogóle jest brane pod uwagę w kontekście filmów animowanych. Prowadzi to bez wątpienia do ukazywania różnych treści prawnych w poszczególnych wersjach językowych. Wykażę te różnice na dwóch przykładach. Pierwszy z nich pochodzi z filmu Toy Story 3 i stanowi odpowiedź lalki Barbie na okrutne władanie zabawkami w przedszkolu przez jedną z nich. 
Tabela 2. Porównanie komunikatów na temat prawa w Toy Story 3

\begin{tabular}{|l|l|l|}
\hline \multicolumn{1}{|c|}{ Angielski } & \multicolumn{1}{|c|}{ Polski } & \multicolumn{1}{c|}{ Francuski } \\
\hline $\begin{array}{l}\text { Authority should derive from the consent } \\
\text { of the governed, not from the threat of } \\
\text { force! }\end{array}$ & $\begin{array}{l}\text { Przyrodzona i niezbywalna godność człowie- } \\
\text { ka stanowi źródło wolności i praw człowieka } \\
\text { i obywatela. }\end{array}$ & $\begin{array}{c}\text { La juste autorité doit émaner du consente- } \\
\text { ment des gouvernés, et non de me- } \\
\text { nace de violence! }\end{array}$ \\
\hline
\end{tabular}

Źródło: opracowanie własne.

Wypowiedź bohaterki ma charakter komiczny. Efekt ten został osiągnięty poprzez zestawienie doniosłości tekstów prawnych z humorystyczną rzeczywistością filmów animowanych i to pomimo faktu, że bohaterowie w tym konkretnym momencie utworu znajdują się w trudnej sytuacji. W oryginalnej wersji językowej twórcy sięgnęli do Deklaracji Niepodległości Stanów Zjednoczonych ${ }^{8}$, a więc dokumentu narodowego o szczególnej wartości kulturowej. Fragment ten dotyczy źródeł władzy, co w kontekście brutalnych rządów głównego antagonisty wydaje się niezwykle trafnym wpleceniem motywu prawa. Polski dubbing korzysta z techniki adaptacji. Jest to „»Technika tłumaczeniowa« polegająca na zastąpieniu pewnej rzeczywistości społeczno-kulturowej »języka docelowego« przez element rzeczywistości, charakterystyczny dla kultury docelowej, znany odbiorcom »tekstu docelowego «" (Tomaszkiewicz, 2001: 22). Wypowiedź bohaterki stanowi cytat art. 30 zd. 1 Konstytucji Rzeczypospolitej Polskiej z 2 kwietnia 1997 roku i dotyczy podstawowego oraz najistotniejszego według obecnego stanu prawnego przymiotu człowieka - godności. Nawiązuje ona do władzy wyłącznie w sposób pośredni. Bohaterka podkreśla przysługujące jej prawa i niejako uprzywilejowaną przez system sytuację prawną, tym samym negując legitymację antagonisty do takiego sposobu rządzenia zabawkami w przedszkolu. W języku francuskim natomiast dokonano wiernego tłumaczenia z angielskiego, wobec czego wypowiedź Barbie ma taki sam wydźwięk jak w oryginale, choć bez wątpienia szanse na zrozumienie przez odbiorcę nawiązania zostały niemalże całkowicie zaprzepaszczone. Ciekawe jest więc to, że nie zdecydowano się zastosować metody przekładu wykorzystanej w polskiej wersji językowej i nie sięgnięto chociażby do Deklaracji Praw Człowieka i Obywatela, co nadałoby dubbingowi bardziej narodowego, a więc dostosowanego kulturowo charakteru (zob. Borowczyk, 2011: 72). Drugi przykład pochodzi z filmu Minionki. Fragment ten jest wypowiadany przez prymasa Anglii podczas koronacji Scarlett O’Haracz na królową Anglii.

8 W oryginale fragment ten brzmi: „That to secure these rights, Governments are instituted among Men, deriving their just powers from the consent of the governed". 
Tabela 3. Porównanie komunikatów na temat prawa w Minionkach

\begin{tabular}{|l|l|l|}
\hline \multicolumn{1}{|c|}{ Angielski } & \multicolumn{1}{|c|}{ Polski } & \multicolumn{1}{c|}{ Francuski } \\
\hline $\begin{array}{l}\text { Will you to your power cause law and ju- } \\
\text { stice... }\end{array}$ & $\begin{array}{l}\text { Przed ludźmi, jako i Bogiem, strzec prawa } \\
\text { i sprawiedliwości... }\end{array}$ & $\begin{array}{l}\text { Promettez-vous de faire régner la loi et la } \\
\text { justice... }\end{array}$ \\
\hline
\end{tabular}

Źródło: opracowanie własne.

W oryginalnej wersji językowej twórcy sięgnęli do ceremoniału koronacyjnego monarchów brytyjskich. Tekst ten jest częścią autentycznej formuły, którą wygłasza metropolita Canterbury i która jest integralną częścią uroczystości. Tłumacze na język francuski ponownie dokonali przekładu zgodnego z przysięgą oryginału, wobec czego raz jeszcze jego wydźwięk nie uległ zmianie. Polska realizacja natomiast różni się od poprzednich. Dodano do niej dwa podmioty, przed którymi królowa jest odpowiedzialna. Wyraz „ludzie” wskazuje na obywatelski charakter władzy, a odwołanie do Boga w swoim symbolicznym wymiarze podkreśla powagę stanowiska i ogrom odpowiedzialności. Ze względu na fakt, że polskie przysięgi koronacyjne składane były po łacinie, nie udało mi się ustalić, czy wypowiadany fragment jest częścią rzeczywistej formuły, czy też stanowi wytwór wyobraźni tłumacza. Jednak bez względu na pochodzenie tej kwestii w polskiej wersji językowej niesie ona zupełnie inne treści w zestawieniu z oryginalnym komunikatem.

Powyższe przykłady wykazały, że ingerencja tłumaczy ma wpływ na przedstawiony fikcyjny porządek prawny. Zmiany te nie są na tyle głębokie, by prowadzity do powstania poważnych sprzeczności między poszczególnymi wersjami językowymi, ale mogą skutkować chociażby wystąpieniem różnic w hierarchii promowanych wartości. Przykład Toy Story pokazał, że prawo krajowe może być wykorzystywane nawet bezpośrednio w celu uzyskania zgodności między dubbingiem a rzeczywistością kulturowo-naukową danego państwa. Uważam, że w kontekście globalnym zjawisko to należy ocenić pozytywnie, ale trzeba zauważyć, iż jego efekt jest w dużej mierze zależny od wieku odbiorcy oraz poziomu edukacji prawnej społeczeństwa. Elementy te mogą okazać się wszakże bezwartościowe, jeżeli widz nie zrozumie nawiązania. Problem ten dotyczy nie tylko sfery prawnej, ale $w$ tej dziedzinie szczególnie łatwo o zmarnowanie potencjału traduktologicznego. Drugi z przykładów można interpretować także jako dostosowanie do społeczeństw narodowych. Angielska wersja językowa jest zaczerpnięta z rzeczywistych źródeł brytyjskich i fakt ten dowodzi występowania głębokich związków kulturowych. Polski dubbing zawiera odwołanie do Boga i religii katolickiej, która pozostaje wszakże dominującą w kraju i jest silnie związana z narodową tradycją. Tłumaczenie francuskie jest o tyle problematyczne, że stanowi przekład z języka angielskiego, 
wobec czego trudno o wskazanie powiązań kulturowych. Można jednak zasygnalizować taki element w opozycji do dubbingu polskiego. Wersja francuska nie nawiązuje do Boga, co można wytłumaczyć głębokim laicyzmem państwa i społeczeństwa. Przytoczone przykłady pokazują, że treści naukowe zawarte w różnych wersjach językowych tego samego tekstu kultury nie są identyczne i ulegają modyfikacjom w wyniku działalności translatorskiej. Taki stan rzeczy potwierdza, że zagadnienie relacji sztuki i nauki jest złożone, toteż powinno być ujmowane wielopłaszczyznowo, co nie znaczy, że nieściśle. Warto także zauważyć, że sam przekład można rozpatrywać w tym kontekście jako kolejny element naukowy - reprezentujący dziedzinę traduktologii. Z całą pewnością dodatkowo komplikuje to zarysowany problem i nadaje mu niejako nowego wymiaru, ponieważ należałoby uwzględnić także ingerencję obcego podmiotu zarówno w treści naukowe, jak i artystyczne, a także zasady, według których ta ingerencja następuje.

Kolejny etap analizy dotyczy rozważań nad funkcjami, jakie prawo pełni lub może pełnić w kontekście odbioru utworu przez widza. Kultura z jednej strony jest kreowana przez społeczeństwo, a z drugiej, jak zostało zasygnalizowane wcześniej, oddziałuje na nie w różnoraki sposób. Filmy animowane są istotnym elementem tego mechanizmu. Mogą one, przede wszystkim wśród najmłodszych, kształtować wzorce postaw społecznych, odgrywając tym samym pewną rolę w procesie wychowania i edukacji, a także wyznaczać trendy handlowe i tym sposobem silniej ingerować w rozwój dziecka. Zdecydowałem się wyróżnić tę funkcję ze względu na sprecyzowaną grupę odbiorców badanych utworów oraz ich niepodważalne oddziaływanie na nich. Rynek reklamowy dąży poprzez najmłodszych do wymuszenia na rodzicach zakupu określonych produktów, które nierzadko są sprzedawane w ramach merchandisingu ${ }^{9}$. Wobec tego należy stwierdzić, że aspekty komercyjny i wychowawczy są ze sobą bardzo silnie powiązane. Nie zagłębiając się w to, jak dane produkty wpływają na zachowanie widzów, co należy do domeny chociażby psychologii rozwoju dziecka, przejdę do właściwej analizy, czyli roli prawa w filmach animowanych jako części zarysowanego powyżej zjawiska.

Często stosowanym zabiegiem jest umieszczanie bohaterów w specyficznych sytuacjach prawnych, czyli sytuacji danego podmiotu wyznaczonej przez normy prawne, w szczególności jeżeli dane zachowanie jest dla niego nakazane, zakazane albo fakultatywne, lub gdy w stosunku do tego podmiotu inny podmiot zachowuje się w określony sposób (Wronkowska, 2005: 163). Chodzi więc o całokształt okoliczności prawnych, które towarzyszą danej osobie. Inną sytuację prawną będą mieli więc na przykład pracownik, władca i kupujący, ponieważ do każdego z nich odnoszą się specyficzne regulacje. Zagadnienie to jest skomplikowane, ale

9 W kontekście badań nad marketingiem nakierowanym na dzieci powstało słowo „kindermarketing” (zob. Jasielska, Maksymiuk, 2010; Webidea, 2017). 
nie sposób przecenić jego przydatności w praktyce. Przeplata się ono z pojęciem roli społecznej. Filmy animowane często korzystają z tej konstrukcji dla różnych celów. Jednym z nich jest z pewnością wzmocnienie treści ideologicznych. Z tej perspektywy Krainę Lodu można interpretować jako utwór przedstawiający wartości feministyczne. Główna bohaterka, Elsa, została wszak obsadzona w roli królowej. Jej panowanie jest jednak tylko punktem wyjścia do ukazania siły postaci. Ukrywa ona magiczne moce po to, by chronić siostrę. Gdy nie udaje jej się to, porzuca państwo i ucieka, by nie stanowić niebezpieczeństwa. Chociaż cierpi, nie ugnie się, dopóki księżniczka Anna nie będzie bezpieczna. Wydaje się, że każdy sukces i każda porażka uwypuklają jej siłę pomimo wrażenia zagubienia w świecie. Kobieta załamuje się dopiero, gdy dowiaduje się o rzekomej śmierci siostry. Prawo służy jednak również jako narzędzie w rękach antagonistów, chcących usunąć Elsę. Książę Hans, rządząc w imieniu księżniczki Anny, najpierw więzi królową, a następnie skazuje ją na śmierć. W ostatecznym rozrachunku monarchini udaje się pokonać wszelkie przeciwności. Na 14 listopada 2017 roku Kraina Lodu była najbardziej dochodowym filmem animowanym, wobec czego trudno jest negować jej kulturowe oddziaływanie. Zawarty w niej przekaz może zatem bez wątpienia mieć wpływ na to, jak wśród dzieci postrzegane są kobiety lub jak żeńska część młodszej widowni myśli sama o sobie. Warto zaznaczyć, że królowa Elsa wpisuje się w kanon tak zwanych księżniczek Disneya, czyli kobiecych postaci będących ulubieńcami żeńskiej (nie tylko, ale przede wszystkim) części młodszych widzów. Świadczy to o niebagatelnym znaczeniu bohaterki w kulturze masowej.

Kolejnym przykładem wykorzystania prawa do przekazania określonych treści jest film Shrek 2. Przesympatyczny ogr poślubia królewnę, przez co staje się królewiczem, a więc jego sytuacja prawna ulega drastycznej zmianie. Wkracza w zupełnie inny świat - po opuszczeniu bagna zaczyna uczestniczyć w życiu salonowym i próbuje nauczyć się funkcjonować według obcych mu regut. Prawne instrumenty służą także jako narzędzia w rękach antagonistów do osiągnięcia ich celów. Książę z Bajki podszywa się pod Shreka, by zdobyć Fionę, która pierwotnie była przeznaczona jemu, a nie ogrowi. Chce poślubić królewnę oraz wejść do rodziny królewskiej. Zależy mu więc na zmianie sytuacji prawnej oraz na związanym z tym faktem awansie społecznym. Ukazana historia porusza problem tolerancji i samoakceptacji. Są to wartości z jednej strony szczególnie istotne dla kultury zachodniej, a z drugiej będące przedmiotem licznych kontrowersji, zwłaszcza co do ustalenia ich dopuszczalnych granic. Poprzez sięgnięcie do konstrukcji prawnych twórcy stworzyli przystępny świat oraz historię, która ma silny potencjał oddziaływania na widza. Warto zaznaczyć, że nie dotyczy to wyłącznie drugiej części Shreka, ale całej serii. Przykłady można by długo mnożyć. Nie chcąc jednak przytaczać 
fabuły większości badanych filmów, ograniczę się do zasygnalizowania pierwszoplanowej roli stosunku służbowego w Zwierzogrodzie (na bazie którego zbudowano ideał pracy, walki z dyskryminacją oraz wątek podążania kobiety-królika za marzeniami), a także realizacji motywu władzy w Toy Story 3 i Królu Lwie. Treści naukowe są więc wykorzystywane do wzmacniania przekazu, co do którego można by powiedzieć, że jest nacechowany pewną ideologią ${ }^{10}$. Nie sposób nie wspomnieć w tym miejscu o zagrożeniach wynikających z takiego stanu rzeczy. Wszakże pozostawienie najmłodszym pełnej swobody interpretacji może stanowić jeden z czynników inwazyjnych w procesie edukacji i wychowania. Jest to „sieć naczyń połączonych", a ich motorem jest kultura konsumpcjonizmu, która w literaturze jest nierzadko krytykowana jako zjawisko niebezpieczne dla dzieci (Krajewska, 2015: 115-127). Treści prawne wydają się więc dostarczać wielu możliwości ich wykorzystania w utworach o charakterze artystycznym lub rozrywkowym.

Należy zauważyć, że współczesne filmy animowane przekazują wartości, których pojawianie się jeszcze w poprzednim wieku stanowiło rzadkość. Możemy to zaobserwować na podstawie porównania Króla Lwa (1994 r.) do pozostałych utworów z podanej we wstępie listy (najwcześniejszy z nich pochodzi z 2003 r.). Główny bohater, samiec lwa, jest następcą tronu - pierwszoplanowym aktorem i postacią, która w toku rozwoju akcji się uczy. Rola kobiet w utworze, zwłaszcza matki i przyjaciółki (przyszłej żony), sprowadza się do pomagania mu w osiągnięciu celu. Nie zachodzą w nich żadne przemiany wewnętrzne, a wręcz pogłębiają one swoje oddanie młodemu lwu. Jest to więc schemat typowy dla utworów dwudziestowiecznych, w których to postaci męskie sprawowały władzę, pozostawały w centrum zainteresowania, a postacie płci żeńskiej głównie były dla nich wsparciem ${ }^{11}$. W literaturze uznaje się, że Shrek (2001 r.) był pierwszą tak udaną próbą odwrócenia stereotypów oraz dostosowania treści przedstawianych w filmach animowanych do standardów i wartości kultury zachodniej (Giddens, 2017: 292). Anthony Giddens słusznie stwierdzit, że takie obrazy należały do marginesu medialnego. Warto zaznaczyć, iż obecnie możemy zaobserwować znaczny wzrost liczby takich tytułów. Królowa Elsa z Krainy Lodu nie jest wszakże zwykłą wiedźmą, ale główną bohaterką, postacią pozytywną i dynamiczną. W Zwierzogrodzie to kobieta-królik spełnia marzenia i dokonuje niemożliwego, a jej kompanem jest lis płci męskiej. Dory z Gdzie jest Nemo? nie jest zwykłą pomocnicą, tylko postacią autonomiczną - ma własną historię, o której powstał osobny film - Gdzie jest Dory? W utworach z cyklu Minionki postacie żeńskie mogą występować jako główni

10 Dostrzegam przy tym fakt, że wszelka ocena w tym zakresie ma charakter subiektywny, dlatego też wystrzegam się przytaczania własnej opinii, stwierdzając jedynie możliwość wystawienia takiej oceny.

11 Z kolei gdy to postacie żeńskie grały pierwszoplanowe role, ich życie sprowadzało się właściwie do pogoni za wymarzonym mężczyzną (zob. Murphy, 2015: 8). 
antagoniści (wspomniana wcześniej Scarlett O’Haracz), a także wybranki głównego bohatera (Lucy, żona Gru). Lucy wydaje się już jednak raczej równorzędną partnerką niż pomocnicą. Podejmuje ona wszak samodzielne inicjatywy oraz przewyższa swojego męża niektórymi umiejętnościami jako tajna agentka. Wraz ze zmianami kulturowymi dokonuje się zmiana podmiotowa z punktu widzenia prawa przedstawianego w filmach. Nie ma już przeszkód, by to kobieta dzierżyła i sprawowała władzę w filmie, a także samodzielnie decydowała o swojej sytuacji prawnej, chociażby poprzez wchodzenie w określone stosunki prawne, na przykład podejmowanie pracy czy zawieranie umów cywilnych. Następuje więc swoiste wyrównanie standardów płci, co oznacza, że rola typowego pomocnika pozbawionego głębi zanika w kulturze. Dzieje się tak dlatego, że awans kobiet nie oznacza degradacji pozycji mężczyzn. Z perspektywy prawa w filmach animowanych sprowadza się to również do poszerzenia kręgu rzeczywistych podmiotów. Postacie wyrosłe ze schematu kompana podejmują teraz autonomiczne decyzje oraz są uwikłane we własne, niezależne stosunki prawne. Lis Nick ze Zwierzogrodu był wszakże przestępcą, zanim zaczął pomagać głównej bohaterce, a Kristoff z Krainy Lodu zajmuje się handlem lodem. Takie zabiegi sprawiają, że bohaterowie stają się bardziej wiarygodni, a ukazana w utworze historia pełniejsza.

Pisząc we wstępie o procesie „nauczania o prawie”, zmierzałem do podjęcia tematu edukacji prawnej i prawniczej ${ }^{12}$, a w szczególności refleksji nad możliwościami wykorzystania potencjału drzemiącego w filmach animowanych. Chciałbym zaznaczyć, że nie postrzegam badanego gatunku jako nadrzędnego w stosunku do innych możliwych do wykorzystania form kulturowych. Moim celem jest jedynie podkreślenie walorów, które wynikają ze szczególnej pozycji tych utworów jako niepodważalnie popularnych. Uważam, że edukacja na tematy tak trudne, a zarazem praktyczne powinna być maksymalnie przystępna, a jedną z najprostszych metod osiągnięcia wysokiej czytelności i przejrzystości materiału może być bazowanie na tekstach, które są uczniom bliskie. Jest to więc pierwszy argument przemawiający za wykorzystaniem ich. Kolejną istotną okolicznością jest fakt, że, jak zostało wykazane wyżej, ukazywane wątki normatywne zostały uproszczone już w samych filmach. Nadają się więc niemalże jako gotowe przykłady do wykorzystania w procesie edukacji. Zawierają one także wiele doniosłych zagadnień wartych podjęcia, których nie sposób wyliczyć, a które zostały zasygnalizowane w niniejszej pracy. Wybór nie ogranicza się wyłącznie do określonych konstrukcji czy założeń systemu prawnego, ale dotyczy także samego porządku, ponieważ możliwe jest odniesienie się bezpośrednio do rzeczywistości polskiej, zagranicznej,

12 Edukacja prawna dotyczy kształcenia obywateli na temat zagadnień prawnych, a edukacja prawnicza odnosi się do podnoszenia poziomu wiedzy prawników oraz studentów prawa. 
a także bazowanie na fikcyjnej. Wariantów jest więc wiele. Trudno jednak o docenienie wartości edukacyjnej jakichkolwiek utworów (także książek czy innych filmów), gdy społeczeństwo traktuje je przede wszystkim jako źródło rozrywki. Nie ma w takim podejściu oczywiście nic złego, jednakże należy zwrócić uwagę na marnowany potencjał dydaktyczny. Chciałbym w tym miejscu przywołać przykład zza Atlantyku, gdzie narodził się ruch Law and Literature ${ }^{13}$. Jarosław Kuisz napisał:

Zgodnie z przewidywaniami pionierów „Prawa i Literatury” ruch ten w Stanach Zjednoczonych wpłynął na edukację w zakresie prawa. Zaskakująca okazała się skala zjawiska: od propozycji pojedynczych zajęć i zapowiedzi renesansu badań interdyscyplinarnych aż po stały element programowy na wiodących wydziałach prawa (law schools) (Kuisz, 2015: 16).

Przytoczony cytat udowadnia, że możliwe jest twórcze wykorzystanie tekstów kultury w procesie edukacji. Dysponujemy niemal nieograniczonymi środkami dydaktycznymi, których implementacja do systemu szkolnictwa może znacząco poprawić jakość nauki. Warto zaznaczyć, że nie dotyczy to wyłącznie książek, jak można by błędnie interpretować z nazwy przytoczonego nurtu. Definicja samego ruchu jest kwestią sporną. Nierzadko można natknąć się na badania nad związkami prawa i kultury w ogóle, które także zalicza się do Law and Literature (zob. Freedman, 2005; Simonsen, 2013). Jako przykład wykorzystania utworów animowanych w sygnalizowanym kontekście w Polsce można podać wykład poprowadzony podczas Poznańskiego Festiwalu Sztuki i Nauki, zatytułowany Czego nie wiedziat Gumball i Zygzak McQueen, czyli co to jest prawo i dlaczego jest tak ważne? ${ }^{14}$. Słuchaczami byli uczniowie drugich i trzecich klas szkoły podstawowej.

Powyższe rozważania prowadzą do wniosku, że motyw prawny stanowi w filmach animowanych jeden z podstawowych elementów konstruujących fikcyjne światy, elastyczny i atrakcyjny ich budulec, a także czynnik pozwalający na manipulację widzem lub przeciwnie - na osiąganie celów dydaktycznych. Co więcej, moim zdaniem niemożliwe jest stworzenie dochodowego filmu animowanego pozbawionego wątków normatywnych, ponieważ taki utwór byłby nieczytelny. Pokazuje to niejako nierozerwalność sztuki i nauki. Tego typu treści są dobierane do dzieł na podstawie kryterium adekwatności do historii, uwypuklenia pewnych postaw oraz wpływania na widzów, podczas gdy inne mogą być umieszczane bez

13 Jest to powstały w XX wieku w Stanach Zjednoczonych ruch, którego zasadniczym celem jest badanie związków między prawem a literaturą. Autorzy podejmują między innymi tematy prawa w literaturze, prawa jako literatury oraz literatury w prawie (zob. Posner, 2009). 
zamiaru twórców. Wydaje się, że z tej perspektywy to nauka jest podporządkowana sztuce. Nie można jednak zapomnieć o ujęciu ruchu Law and Literature, w którym bez wątpienia to treści artystyczne zostały dostosowane czy też wykorzystane do potrzeb naukowych. Powyższe rozważania prowadzą do wniosku, że relacje nauk prawnych (szerzej: nauki w ogóle) i filmów animowanych (ponownie: całej sztuki) nie są i nie mogą być trwale ustalone - ulegają ciągłym zmianom zarówno ze względu na postęp obu tych dziedzin, jak i na kontekst społeczny i kulturowy. Wobec powyższego najbliższe prawdzie wydaje się stwierdzenie, że związki te są z jednej strony bardzo bliskie (szczególnie że obie te formy działalności ludzkiej mogą czerpać z siebie nawzajem), a z drugiej niestałe (co widać na przykładzie porównania tekstu kultury jako zamkniętego, niezależnego bytu, oraz celów, do jakich można go wykorzystać).

\section{Bibliografia}

Borowczyk P. (2011), Różne oblicza Asterixa i zielonego ogra. Studium nad tłumaczeniem dialogów, [w:] I. Kasperska, A. Żuchelkowska (red.), Przekład jako produkt i kontekst jego odbioru, Poznań: Wydawnictwo Rys, s. 71-84.

Clouet R., Sánchez Hernández A. (2004), Remarques sur la traduction littéraire: un exemple pratique autour des traductions espagnole et anglaise de „L La Place” de A. Ernaux, „Anales de Filologia Francesca”, nr 12, s. 67-79.

Freedman M. (red.) (2005), Law and Popular Culture, 0xford-New York: Oxford University Press.

Giddens A. (2017), Socjologia, przeł. A. Szulżycka, Warszawa: Wydawnictwo Naukowe PWN.

Jasielska A., Maksymiuk R.A. (2010), Dorośli reklamuja, dzieci kupuja. Kindermarketing ipsychologia, Warszawa: Wydawnictwo Naukowe Scholar.

Krajewska A. (2015), Konsumpcjonizm jako zagrożenie dla dzieci i młodzieży. Wyzwania dla edukacji, „Journal of Modern Science”, vol. 3(26), s. 115-127.

Kuisz J. (2015), Prawo i wyobraźnia. 0 ruchu „Law and Literature”, [w:] J. Kuisz, M. Wąsowicz (red.), Prawo i literatura. Szkice, Warszawa: Wydawnictwo Naukowe Scholar, s. 14-35.

Making Sense of the Dollar's Effect on Global Box Office in 2016, 2017, https://www.motionpictures.org/press/making-sense-of-the-dollars-effect-on-global-box-office-in-2016/ (dostęp: 14.06.2018).

Monjean-Decaudin S. (2012), La Traduction du droit dans la procédure judiciaire ,,'Les Cahiers de la Justice”, vol. 2, nr 2, s. 127-140.

Murphy J.N. (2015), The role of women in film: Supporting the men - An analysis of how culture influences the changing discourse on gender representations in film, http://scholarworks.uark.edu/cgi/viewcontent.cgi?article=1001\&context=jouruht (dostęp: 14.06.2018).

The Numbers, All Time Worldwide Animated Box Office, https://www.the-numbers.com/box-office-records/worldwide/all-movies/cumulative/all-time-animated (dostęp: 14.11.2017).

Posner R.A. (2009), Law and literature, Cambridge: Harvard University Press.

Radbruch G. (2008), Pięć minut filozofii prawa, przeł. J. Zajadło, [w:] J. Zajadło (red.), Antologia tekstów dotyczących praw człowieka, Warszawa: Biuro Rzecznika Praw Obywatelskich, s. 241-242.

Schaffer D.R., Kipp K. (2015), Psychologia rozwoju. Od dziecka do dorosłości, Gdańsk: Wydawnictwo Harmonia Universalis.

Simonsen K.M. (2013), Law and Justice in Literature, Film and Theater. Nordic Perspectives, Berlin: de Gruyter.

Tomaszkiewicz T. (2001), Terminologia tłumaczenia. Przekład i adaptacja, Poznań:Wydawnictwo Naukowe Uniwersytetu im. Adama Mickiewicza.

Wang M. (2012), Research on the Relationship between Story and Popularity of Animated Movies, https://docs.lib.purdue.edu/cgi/viewcontent.cgi?article $=1071 \&$ context=techmasters (dostęp: 7.05.2018).

Webidea (2017), Kindermarketing - zadanie specjalne dla odważnych, http://www.webidea.pl/kindermarketing-zadanie-specjalne-dla-odwaznych/ (dostęp: 18.07.2018).

Wronkowska S. (2005), Podstawowe pojęcia prawa i prawoznawstwa, Poznań: Ars boni et aequi. 